\title{
Güdüleyici Dil ve İç Girişimcilik Arasında İşgören Sesliliğinin Aracı Rolü
}

\author{
The Mediatory Role of the Employee Voice between Motivational Language and \\ Entrepreneurship
}

\begin{abstract}
Serdar YENER * Sultan SALUR **

Öz: Günümüzde rekabet avantajı elde etmek isteyen işletmeler giderek daha yoğun bir şekilde insan kaynaklarının verimli ve etkin kullanımı için çalışmaktadır. İşletmeler sürdürülebilirliklerinin yenilik ve yaratıcılıktan geçtiğine daha fazla inanmaktadırlar. Çalışan psikolojisini anlama gayretinde liderlik kuramlarının her geçen yeni bir boyutu çalışmalara konu olmaktadır. Örgütü tüm boyutlarıyla güçlendirme araçlarından bir tanesi olarak liderlerin kullandığı güdüleyici dil görülmektedir. Güdüleyici dil yoluyla oluşan destekleyici örgütsel ortamda çalışanların herhangi bir önyargı veya tepkiye maruz kalmadan verimlilik ve etkinliği artıracak öneri ve tekliflerini sunacakları düşünülmektedir. Bu bağlamda liderlerin kullanmış olduğu güdüleyici dilin çalışanların iç girişimciliklerine olan etkisinde işgören sesliliğinin aracı rolü irdelenmiştir. Çalışmanın örneklemini Sinop'ta faaliyet gösteren yerel bir tekstil üretim fabrikasının çalışanları oluşturmaktadır. SPSS 21 ve Hayes Macro 2.15 ile yapılan istatistiki analizlere göre işören sesliliğinin güdüleyici dil ve iç girişimcilik arasında aracı rolü gözlemlenmiştir.
\end{abstract}

Anahtar sözcükler: Güdüleyici Dil, İç Girişimcilik, İşgören Sesliliği

Abstract: Today organizations are trying intensively to use their resources in an efficient and productive way in order to gain competitive advantage. They believe that their sustainability is a result of innovation and creativity. Different dimensions of leadership theories are the subject of different research studies of employee psychology. The leader's motivational language is seen as one of the tools in the business empowering process. Employees are allowed to speak without fear of interpersonal reaction and pressure, in the motivational dialogue process, in order to increase both efficiency and productivity. Within this context the effect of the leader's motivational language concerning entrepreneurship and the mediating effect of the employee voice is questioned. The employees of a local factory manufacturing textiles formed the research sample. The mediating effect of the employee voice was studied using this research data with the results obtained through statistical analysis, which was completed by means of SPSS 21 and Hayes Macro 2.15.

Keywords: Motivational Language, Entrepreneurship, Employee Voice

\section{Giriş}

İşletmeler giderek artan bir şekilde çalışanlarının bilgi, deneyim ve düşüncelerinden rekabet avantajı elde etmek üzere yararlanmaktadır. Dünyada bunun sonucu olarak bilgi ve bilgi kaynağ olabilecek çalışan talebine ilgi artmaktadır (Mayfield \& Mayfield 2004). Bilgi ve bilgi kaynağı

\footnotetext{
* Yrd. Doç. Dr., Sinop Üniversitesi, İ̈BF, İşletme Bölümü, Sinop, serdaryener@sinop.edu.tr

** Yrd. Doç. Dr., Sinop Üniversitesi, İ̈BF, İktisat Bölümü, Sinop, ssalur@sinop.edu.tr
} 
rolündeki çalışana olan ihtiyaç işletmeleri kendi kaynaklarının tümünü etkin bir şekilde kullanmaya itmektedir (Robbins 2003). Liderlerin çalışanlarından beklentileri çalışanları bu beklentileri gerçekleştirmeye itecek liderlik davranışlarını gerekli kılmaktadır (Capelli 2001). Liderlerin göremediği firsatları ya da verimlilik veya etkinliği olumsuz etkileyen örgütsel aksaklıkları farkederek uygun örgütsel ortam ve destekle inovasyon sürecinden geçirip iç girişimcilikle sonuçlandıracak çalışanlar hemen hemen her işletmenin temel ihtiyaçları olarak görülmektedir. İşletmenin kendi kaynaklarıyla sürdürülebilir rekabet avantajını sağlamasının tek yolu olarak iç girişimcilik görülmektedir.

İç girişimcilik olgusu ya da diğer adıyla kurumsal girişimcilik davranışı mevcut işletmede verimlilik ve etkinliği artıracak bir fırsatın keşfedilerek bunun ekonomik değere dökülmesini ifade etmektedir (Pinchot 1985). Girişimcilik yanında iç girişimciliğe yönelmenin en büyük nedeni olarak kaynak temelli bakış açısına göre sürdürülebilir rekabet avantajı elde etmek isteyen liderlerin işletmelerini kendi potansiyelleriyle işletmelerini sektörün seviyesine uydurup yeniliklerle işletmenin topyekûn performansını artırma çabasıdır (Antoncic \& Hisrich 1990). Girişimciliğin alanyazına kazandırılmasından yüzyıllar sonra iç girişimciliğin alanyazına kazandırılmasının birtakım nedenleri vardır. İç girişimciliğin popüler olmasından sonra da girişimciliğin popülerliğini korumasının bir takım nedenleri vardır. Bu bağlamda mevcut işletmelerde vekalet maliyeti, insan kaynaklarının işletmeler arasında yer değiştirebilmesi, yetersiz fon sağlanması, katı ve bürokratik yönetim şekilleri iç girişimcilik potansiyellerinin kullanılamamasının nedenleri olarak girişimciliği belirleyen faktörler olmaktadır (Helfat \& Lieberman 2002). Bunun yanında iç girişimciliğin popüler olmasının nedenleri olarak pazara giriş stratejilerinin birleştirilmesi, işletmenin mevcut imkanlarıyla üretilen yan ürünlerin kayda değer pazar performanslanı (Klepper \& Thompson 2006), iç girişimciliği destekeleyen örgütsel faktörler, iç girişimcilik uygulamalarının örgütün genel performansı üzerine olan etkileri ve iç girişimcilerin kişilik özellikleri görülmektedir (Fayolle 2004).

İç girişimcilik davranışının belirleyenleri olarak fırsatları farketme, yeni fikirler sunma, yeni ürün tasarımları, kaynakların farklı kombinasyonuyla yeni alanlarda kullanımı, sinerji oluşturma, destekleyici yönetim, kaynak sağlama, proaktif davranışlar, risk alma, planlama ve örgütleme gibi faaliyetler görülmektedir (de Jong \& Wennekers 2008). İşletmelerde iç girişimciliği belirleyen anahtar uygulamalar ise inisiyatif kullanma, fikir ve önerileri dile getirebilme, liderlik etme, sorumluluk üstlenme, risk alma davranışları olarak görülmektedir (de Jong \& Wennekers 2008).

Güdüleyici dil lider ve üyenin arasındaki iletişim dilinin geliştirilmiş bir önerisidir (Sullivan 1986; Mayfield et al. 1995). Güdüleyici dil kullanımını liderlerin yönetim sürecinde çok önemli üç araçla gerçekleştirdiği ifade edilir. Bunlar çalışanları yönlendirme, empatik olma ve çalışma sürecine anlam katma olarak görülmektedir (Mayfield \& Mayfield 2004). Sullivan (1988) güdüleyici dil kullanımıyla yukarıdaki araçlar sayesinde çalışanların sinerjik bir şekilde işletmenin çıtılarına olumlu etki yaptığını ifade etmektedir. Çalışanları yönlendirme, empatik olma ve sürece anlam katma araçlarının eşgüdümlü bir şekilde kullanımı liderlerin iletişim dilini stratejik kullanmalarını sağlamaktadır. Güdüleyici dil kullanımının işletmelerde çalışan memnuniyeti, yüksek performans, inovasyon gibi birçok olumlu sonucunun ortaya çıktığı çalışmalar (Mayfield \& Mayfield 2004) güdüleyici dil kullanımının iç girişimciliği yordayabileceğini düşündürmektedir.

İşgören sesliliği olgusu alanyazında farklı açılardan farklı şekilde ifade edilmiştir. İşgören sesliliği olgusu çalışanların örgütte duydukları rahatsızlık veya kaygıları ifade edebilme derecesidir (Arslan \& Yener 2015). İşgören sessizliği olgusu çalışanların maruz kaldığ 1 farklı faktörlerden dolayı kendisini psikolojik olarak soyutlamasını ifade ederken işgören sesliliği tam 
tersi olarak çalışanın inisiyatif kullanmasını ifade etmektedir. Güdüleyici dil kullanımının oluşturacağ 1 etkileşimli ve destekleyici bir örgüt çevresinde çalışanların kendilerini ifade etmelerinin kolaylaşacağı düşünülebilir. Kişilerarası güvenin, hoşgörünün ve saygının olmadığ 1 çalışanların konuşmaktan kaygı duyduğu bir ortam olmaktadır (Yener 2015). Bu bağlamda liderlerin güdüleyici dil kullanımının sağlayacağı destekleyici, hoşgörülü, saygılı bir ortamda çalışanların örgüt sürecinde yaşadığı deneyim, duyduğu kaygı veya önerilerini ifade etmelerini sağlayabileceği düşünülmektedir.

Güdüleyici dil kullanımının çalışanların potansiyellerini ortaya koymasını kolaylaştırdığı, performanslarını artırdığı yada olumlu davranış olarak ifade edilen sorumluluk alıp inisiyatif kullanıp işletmenin faydasına çalışmasını sağladığı farklı çalışmalarda gözlemlenmiştir. Güdüleyici dil kullanımının çoğunlukla konu olduğu okul ve öğrenme çalışmalarında ise güdüleyici dil kullanımının öğrenmeyi olumlu etkilediği ortaya konulmuştur. İç girişimciliğin dayandığ faktörlerden olan yenilik ve yaratıcılık faktörlerinin öğrenme vb. davranışlarla olan olumlu ilişkisi düşünüldügünde güdüleyici dil kullanımının iç girişimciliği olumlu destekleyebileceği düşünülebilir.

Örgütte çalışanların kendilerini, kaygılarını ya da önerilerini ifade edebilme derecesinin yükselmesi proaktif, yenilikçi ve yaratıcı davranışların artışına yol açtı̆̆ farklı çalışmalarda ortaya konmuştur (Arslan \& Yener 2015). Bu bağlamda iç girişimciliğin belirleyenleri olarak da görülen yenilikçi, yaratıcı ve proaktif davranışların artışının iç girişimciliği artırabileceği yani olumlu işgören sesliliği davranışının iç girişimciliği olumlu olarak etkileyebileceği düşünülmektedir.

İç girişimcilik araştırmalarının çoğu genel ve spesifik insan kaynağı kuramına (Becker 1964) dayandırılırken araştırmamızda iç girişimcilik sürecinin oluşumunda güdüleyici dil kuramı (Sullivan 1988), işgören sesliliğinin dayandırıldığı kaçma-konuşma-sadakat kuramı (Hirscman 1970) ve sosyal mübadele kuramından (Blau 1964) yararlanılmıştır.

\section{Literatür Taraması ve Hipotez Oluşturma}

\section{Güdüleyici Dil ve İç Girişimcilik İlişsisi}

İç girişimcilik; sürdürülebilir rekabet avantajı elde etmek maksadıyla işletmenin verimlilik ve etkinliğini artıracak yenilikçi fikirlerin uygulamaya sokulması süreci olarak tanımlanabilir. Girişimcilik bağlamında tanımlanan iç girişimcilik olgusunun birçok yordayanı girişimcilik olgusunun da yordayanı olarak alanyazında çalışmalara konu olmaktadır (Kuratko et al. 1999). Bunlardan en öne çıkanlarından bir tanesi olarak yenilikçilik davranışı görülmektedir (Pinchot 1986). İşletme içindeki verimlilik ve etkinlik açısından olumlu fikirlerin düşünce seviyesinden yukarı çıkarak uygulama için teşvik edildiği işletmelerde iç girişimcilik kültürünün olduğu kabul edilmektedir (Moriano et al. 2011). Hatta iç girişimcilik davranışı sektörün içinde sürdürülebilir rekabet avantajına sahip olmak isteyen örgütler için zamana yayılmış yenilenme veya yeniden yapılanma aracı olarak da kabul edilmektedir. Bir anda yapılan radikal değişikliklerin oluşturacağı olumsuz etkilerden korunmak için iç girişimcilik kültürüyle zamana yayılmış yeniliklerin işletmelerin idamesini sağlayabileceği düşünülmektedir.

Yenilikçilik olgusunun yanında sezgisel (proaktif) davranışlar ve risk alma davranışı girişimcilik gibi iç girişimcilik olgusunun da belirleyenleri olarak ifade edilmektedir (Rauch et al. 2009). Çalışanların sezgisel davranışlar göstermesi çalışanların diğer çalışanlara göre ek sorumluluk alarak rol üstlenerek yani bir nevi risk alarak davranmasını ifade etmektedir. Organizasyonda iç girişimcilik davranışlarının organizasyon ve çalışana farklı yansımaları olmaktadır. Organizasyon için iç girişimcilik davranışlarının finansal ve yapısal yükleri bulunmaktadır. Bunun yanında yönetim açısından iç girişimcilik davranışlarını destekleyecek bir mantığının olması organizasyo- 
nun diğer bir ihtiyacıdır. Çalışanlar açısından iç girişimcilik davranışı sezgisel davranmayı, risk almayı gerekli kılmaktadır. Çalışanların kişilik özelliği olarak firsatları fark edebilme veya yenilikçi bakış açısına sahip olma gibi özellikleri olabilir. Bunun uygulamaya dökülmesi için sezgisel davranma (proaktif davranışlar) ve risk alma davranışı gereklilik olarak görülmektedir (Hisrich \& Peters 2002). Çalışanın içinde bulunduğu organizasyonda risk alabilmesi uygun psikolojik ortamı yani güven ve destekleyici ortamı gerekli kılmaktadır (Yener 2015).

Güdüleyici dil kuramı örgütlerde kişilerarası kullanılan dilin stratejik kullanımıyla örgütte olumlu değişiklikler oluşturabileceğini önermektedir (Sullivan 1988). Liderlerin örgütün hedefleri doğrultusunda çalı̧̧anları etkilemek ve yönlendirmek için güdüleyici dil kullandıkları bildirilmektedir. Liderlerin günlük etkileşimlerinde kullandıkları dilin çalışanların davranışlarında ölçülebilir değişikliklere yol açabileceği çalışmalarda gözlemlenmektedir (Mayfield \& Mayfield 1995). Sullivan (1988) güdüleyici dilin üç fonksiyonuyla çalışanların davranışlarında değişiklik oluşturduğunu ifade etmektedir. Liderler yönlendirme (direction giving), empati kurma (empathic language) ve anlam oluşturma (mean making) fonksiyonlarını eş güdümlü kullanarak çalışanların davranışlarında olumlu değişiklikler oluşturmaktadır (Sullivan 1988).

Güdüleyici dilin yönlendirici fonksiyonu yerine uygun eylemler (perlocutionary acts) olarak adlandırılmaktadır (Mayfield \& Mayfield 2007). Liderler motivasyon dilin yönlendirici fonksiyonuyla çalışanların işe yönelik bilgi ihtiyaçlarını karşılamaktadır. İçinde bulunulan örgütte işle ilgili blinmeyenler çalışanları en fazla strese sokan faktörlerden biri olmaktadır (Yener 2015). Bu bağlamda çalışanların ihtiyacı olan ve kullanabileceği bilginin çalışana sağlanması çalışanın kendini rahat hissetmesini sağlayabilir. Çalışma ortamıyla ilgili ihtiyaç duyulan her türlü bilgiye ulaşılabilecek bir örgüt çalışanlar için risk kaynağı olmaktan çıkacağı gibi aynı zamanda örgütüne karşı güven duymasını da sağlayabilir.

Liderin güdüleyici dil kullanımının diğer fonksiyonu olan empatik iletişim kurma davranışı kendini çalışanın yerine koyarak içinde bulunulan durum ve süreçte çalışan gibi düşünmesini gerekli kılmaktadır. Güdüleyici dilin empatik olma fonksiyonu edim söz edimi (Illocutionary acts) olarak adlandırılmaktadır (Mayfield \& Mayfield 2007).Bu bir anlamda LMX (leader-member exchange theory) kuramının ifade ettiği gibi liderin her bir çalışana özel bir iletişim yolu kurmasını ifade etmektedir. Kendini çalışanın yerine koyarak içinde bulunulan durumda çalışanın duygu ve düşüncelerini anlamaya gayret eden bir lider kişiye özel iletişim kurarak çalışana kendisini özel hissettirebilir. Bu bağlamda sadece güdüleyici dil kuramı (Sullivan 1988) ve LMX kuramı değil aynı zamanda sosyal mübadele kuramına (social exchange theory, Blau 1964) göre de her bir çalışanın kendisine lider tarafından gösterilen bu ayrıcalıklı davranışa olumlu tepki vererek örgüt lehine daha fazla sorumluluk alarak rol üstlenebileceği, örgütle kendisini özdeşleştirebileceği önerilmektedir.

Güdüleyici dil kuramının son fonksiyonu olarak önerilen anlam oluşturma (meaning making) örgütün çalışan için ifade ettiği anlamın zenginleştirilmesini önermektedir. Güdüleyici dilin anlam oluşturma fonksiyonu düz söz edimi (locutionary acts) olarak adlandırılmaktadır (Mayfield \& Mayfield 2007). Çalışan içinde bulunduğu örgütü örgütün misyonu, vizyonu, kuralları, prensipleri, yapıs1, kültürü ve değerleri doğrultusunda anlamlandırmaktadır. Bu bağlamda anlamlandırma seviyesi yükseldiğinde örgütle özdeşleşen çalışan bu seviye düşük olduğunda çalıştığı örgüt için anlamlı duygulara sahip olmamaktadır. Bu süreçte yaşanılan tecrübeler ve uygulamalar örgütün misyon, vizyon, prensip, değer ve kültürününün çalışanda anlam oluşturmasını sağlar. Anlam oluşturma süreci genelde gayri resmi olup yaşanılan deneyimler ve uygulamalarla yerleşmektedir. Örgütün adaleti, sadakati, vefası, fedakarlığı vd. özellikleri çalışan nezdinde farklı zaman yer yerlerde örgütün uygulamalarıyla anlamlandırılmaktadır. Güdüleyici dilin yukarıda ifade edilen üç 
fonksiyonunun etkileşim ve eşgüdümlü kullanımıyla birtakım etkiye sahip olabileceği ifade edilmektedir.

Risk alma ve sezgisel olma iç girişimcilik davranışının ana gerekliliklerinden olup her ikisinin oluşması için çalışan ve liderin birtakım sorumlulukları bulunmaktadır. Her iki davranışta çalışanın gönüllülüğüne dayanmaktadır. Bu bağlamda çalışanın ek rol üstlenerek ve sorumlululuk alarak risk alıp sezgisel davranıp işletme lehine olumlu davranışlar sergilemesi için liderin bu ortamı sağlamasının gereklilik olduğu düşünülmektedir (Yener 2015). Liderin kullanacağı güdüleyici dilin etki-söz edimiyle çalışanın ihtiyacı olan bilginin sağlanması çalışanda belirsizlik olgusunu düşürebilir. İş stresinin en büyük belirleyenlerinden bir tanesi olan işe ilişkin belirsizlik olgusunun ortadan kalkmasıyla çalışanda bir rahatlama oluşabilir. Bunun yanında liderin empatik olmasıyla çalışanla kuracağı etkili birebir ilişki çalışanda lidere ve örgüte güven duygusunu oluşturabilir. Güdüleyici dil kullanımının üçüncü fonksiyonu olan düz söz edimiyle örgütün çalışanların davranışlarına bakış açısı çalışanda örgüte karşı bir algı oluşturmaktadır. Daha önceden örgüt yararına davranıp ölçülü risk alıp sezgisel davranışlar sergileyen çalışanların başarısızlık vb. durumların sonucunda örgütte maruz kaldığı davranış örgüt iklimini belirler. Bu durum çalışanların sonraki davranışlarını etkiler ve belirler. Güdüleyici dilin farklı fonksiyonlarının eşgüdümlü kullanılması işgörende sadakat olgusu oluşturarak işletme lehine sorumluluk üstlenmesini sağlayabilir (Bass 1985). Yukarıda anlatılanlar ışığında çalışanların güdüleyici dilin etkin kullanımıyla belirsizlik duygusunu yaşamadığı, empatik bir yönetim süreciyle kendini değerli hissederek güven duyduğu ve başarısızlık durumunda günah keçisi yerine konulmadığı örgütlerde ölçülü risk alarak etkinlik ve verimliliği artıracak yenilikçi fikirleri uygulamaya sokabileceği değerlendirilmektedir. Bu bağlamda aşağıdaki hipotez oluşturulmuştur.

$\mathrm{H}_{1}$ Liderin güdüleyici dil kullanımı iç girişimcilik davranışını olumlu ve anlamlı şekilde etkilemektedir.

\section{Güdüleyici Dil ve İşgören Sesliliği İlişkisi}

İşgören sesliliği örgütün verim ve etkinliğinin artırılması için çalışanların sahip olduğu bilgi, deneyim ve tecrübelerini örgütün faydası için dile getirilmesi davranışını ifade etmektedir (Detert \& Burris 2007). İşgören sesliliği olgusu eleştiri gibi işletme içindeki otoriteler açısından rahatsız edici bir şekilde de olabilir (Arslan \& Yener 2016). Örgütlerde işgören sesliliğinin seviyesi çalışanın bu davranışları gösterme seviyesi olarak da gösterilir. İşgören sesliliğinin örgütlerde en büyük fonksiyonlarından bir tanesi karar alma sürecine olan etkisidir (Levine \& Tyson 1990). Örgütlerdeki liderlik tarzının göstergesi olarak da görülebilen işgören sesliliği olgusu alanyazında kaçma-konuşma- sadakat kuramına dayandırılmaktadır (Hirschman 1970). Hirscman (1970) çalışanların kendilerini ifade edebilecekleri psikolojik iklime sahip örgütlerde endişe, kaygı ve önerilerini herhangi bir korku ve baskı hissetmeden ifade ederken bunun tersi durumlarda bask1 ve psikolojik risk algıladığı ortamlarda konuşmaktan kaçtığını ifade etmektedir. Kurama göre çalışanların konuşabilecekleri örgüt ikliminde zamanla sadakat davranışları olan sorumluluk alma davranışlarını da sergileyebilecekleri önerilmektedir.

İşgören sesliliği üzerine yapılan farklı çalışmaların etkisiyle işgören sesliliği iki farklı şekilde kullanılmaya başlanmıştır. İşgören sesliliğinin karar alma mekanizmasındaki rolünü gösteren işgören sesliliği doğrudan işgören sesliliği olgusu olarak adlandırılırken, çalışanların kaygı ve sıkıntılarını ifade eden işgören sesliliği olgusu dolaylı işgören sesliliği olgusu olarak ifade edilmektedir (Levine \& Tyson 1990). Bununla birlikte dolaylı işgören sesliliği genellikle sendika vb. işçi birlikleri süreciyle işlemektedir. Dolaylı işgören sesliliğinin aracı rolündeki sendikalar her ne kadar çalışanların iş kaynaklı endişelerini dile getiriyor olsa da yaşanılan endişe ve kaygıların 
işveren ve işçi temsilcilerinin arasındaki görüşmelerde konuşulup işverenler tarafindan karar alma sürecinde dikkate alınması dolaylı işgören sesliliğinin de karar alma mekanizmasına etkisini ortaya koymaktadır. İşgören sesliliği çalışanların gönüllü olarak sorumluluk alıp rol üstlenmesini önermektedir (van Dyne et al. 1995). Çalışanların sorumluluk hissederek göstermiş oldukları ekstra rol davranışı aşağıdaki şekillerde ortaya çıkmaktadır;

1. Destekleyici-Teşvik Edici İşgören Sesliliği: Yapısal ve zorunlu nedenlerden dolayı çalışanların “iş"ten dolayı hissettikleri endişe ve kaygıyı azaltmak için çalışanlar üzerindeki yapısal ve zorunlu baskının dengelenmesi için çalışanlar arasındaki eşgüdümün sağlanmasını ifade eder. Bu tür işgören sesliliğinin endişe verici durumu değiştirmek ya da ortadan kaldırmak için bir sesliliği söz konusu olmaz fakat endişe dile getirilir. Durumun sonucunda olan endişenin etkilerini azaltıcı seslilik söz konusudur.

2. Destekleyici-Koruyucu Davranış: Örgütte rahatsızlık ve endişenin kaynağı durum karşısında buna maruz kalan üyenin desteklenerek güçlendirilmesini ifade eder. İstenmeyen duruma maruz kalan yetki ve güç açısından zayıf üyenin diğer üye ve liderler tarafindan desteklenmesi üyelerde güven olgusunu oluşturmaktadır.

3. Meydan Okuyucu - Koruyucu Davranış: Örgüt içinde yapılan hataların ve hata sahibinin yapıcı bir eleştiri sonucunda örgüte kazandırılması amaçlanır. Bu bağlamda objektif değerlendirme kriterleri ve liyakat standartları ölçü olarak alınır.

4. Meydan Okuyucu - Teşvik Edici Davranış: Yapılan hataların ve hata sahibinin sadece eleştirilmesinden ziyade objektif bir eleştiri sürecinin sonunda hatanın düzeltilerek örgüt yararına davranış haline getirilmesini ifade eder. Bu bağlamda belki de en faydalı işgören sesliliği formu bu şekilde oluşmaktadır (van Dyne et al. 1995).

Alanyazında işgören sesliliği çalışmaları işgören sessizliği olgusu bağlamında yapılmıştır. Buna göre işgören sesliliği olgusunu alanyazına kazandıran Van Dyne ve LePine (1998) ve daha sonra van Dyne vd. (2003) işgören sesliliğinin 3 çeşidi olduğunu ifade etmektedir. Bunlar:

1. Kabul Edilen Seslilik: İşgörenin kendilerine özgüveni olmamasının yanında kaygı duyduğu durumu değiştirmek için başkalarına bağımlı olma durumudur. Bu tür bireyler etkin olan diğer çalışanların kararlarına uyarak durumu kabul eder. Kabul edilen işgören sesliliği özyeterlik olgusunun sonucu oluşmaktadır.

2. Savunma Amaçlı Seslilik: İşgörenlerin endişe ve kaygı duyduğu istenmeyen bir durumu eleştirirken durumu kendilerine göre de yorumlayıp örgütsel kaygılarının yanında bireysel kaygıların da dile getirilmesidir.

3. Örgüt Yararına Seslilik: Çalışanların liderlik ve teşkilata duyduğu mutlak itaatle birlikte sorunların çözümü için topyekün kişilerarası eşgüdüm ve işbirliği ile yapıcı eleştiri yapılmasıdır. Bu tür seslilik olgusunda işgörenlerin yenilikçilik ve yaratıcılık yönünde sezgisel (proaktik) davranışlar yüksek olarak görülmektedir.

İşgören sesliliği yoluyla çalışanların endişe ve kaygılarını ifade etmeleri için kendilerine karşı bir risk hissetmemeleri gerekmektedir (Edmondson 1999). Çalışanların kendilerini güvende hissetmesini sağlayan bir takım lider davranışları vardır. Yapılan araştırmalar çalışanların işle ilgili sorun yaşamaları durumunda lidere ulaşabilmeleri (Milliken et al. 2003), liderin sorumluluk üstlenerek çalışanlarla iletişim seviyesinde bulunması çalışanların kendini güvende hissederek konuşmasını sağlayabilir. Van Dyne ve LePine (1998) çalışanların işle ilgili endişe duydukları bir durumu dile getirme motivasyonunun bir değerlendirme sonucunda oluştuğunu ifade etmektedir. Çalışanlar konuştuklarında elde edecekleri getirinin konuşmanın çalışana maliyetinden daha fazla olduğunu değerlendirdiğinde konuşmayı tercih etmektedirler. Çalışanın kaygı duyduğu bir 
durumu dile getirmesinin sonucundaki getiriler problemin çözülmesi, takdir veya taltif alınması, ödüllendirilmesi, vicdani olarak rahatlama ve iyi hissetme olabilirken çalışana maliyeti ters tepkiler, azarlanma, psikolojik baskıya maruz kalma olabilir (Milliken et al. 2003). İsgörenin değerlendirmesi sonucu vardığı kararla seslilik ya da sessizliği tercih edebilir. Sesliliği tercih etmesini sağlayan psikolojik olarak güven duyması işgörenin geçmiş deneyimleri sonucu oluşmaktadır. İşören sesliliğinin hedefi lider olmaktadır. Çünkü işgören sesliliğe konu olan işe ilişkin endişe ve kaygıları liderin çözebileceğini düşündüğü için sesliliği kullanır. Bir başka açıdan bakıldığında işgören sesliliği çalışanın kendi düşüncelerini liderine ifade etmesi ve liderin düşüncelerini çalışana ifade etmesi bunların karşılıklı ve etkileşim içinde olması diyaloğun tanımına uymaktadır. Bass ve Riggio (2006) liderlerin bu şekilde diyalog çabalarının işgörenlerin düşüncelerini, kaygılarını, önerilerini çekinmeden ifade etmelerini sağlayacağını iddia etmektedirler. Liderin bu davranışı işletmenin verimlilik ve etkinliğini artırma amaçlı yapması liderin işletmenin tüm kaynaklarının bilincinde olduğunun göstergesi de olmaktadır.

$\mathrm{Bu}$ bağlamda lider açısından bakıldığında işgören sesliliğini verimlilik ve etkinliği sağlama sürecinde işletme için faydalı hale getirme liderin davranış şekline bağlı olmaktadır. Liderin sağlayacağı rahatlatıcı ortam çalışanın endişe kaygı duymadan sorunları, eleştirileri ve çözüm önerilerini sunmasını sağlayabilir. Güdüleyici dil kuramının etkisöz, edimsöz ve düzsöz olgularıyla oluşturacağı empatik ve kişilerarası iletişim işgörenin kaygı, eleştiri ve önerilerini dile getirmesini kolaylaştırırken düzsöz edimiyle işgören sesliliği davranışının sonucunda çalışanın kendini işletmeyle özdeşleştirmesi sağlanabilir. Bu bağlamda aşağıdaki hipotez oluşturulmuştur.

$\mathrm{H}_{2}$ Liderin güdüleyici dil kullanımı işgören sesliliğini olumlu ve anlamlı bir şekilde etkilemektedir.

\section{İşgören Sesliliği ve İç girişimcilik İlişskisi}

İç girişimcilik olgusu yenilikçilik, yaratıcılık ve risk alma davranışlarından olumlu olarak etkilenmektedir. Bass ve Riggio (2006) çalışanların konuşmak için cesaretlendirilmesinin işletmelerde yenilikçi davranışların yolunu açacağını iddia etmektedir. Çalışanların işe ilişkin konuları dile getirmek için yaptığ 1 bireysel değerlendirmeleri ve içsel motivasyonunu karşılaştığ durumlarda yaptığı getiri ve götürü karşılaştırmaları sonucu elde ettiği ifade edilmektedir (Bass 1985). Bu bağlamda bireyin yaptığı bireysel değerlendirmeler o işletmedeki işgören sesliliğinin de göstergesi olmaktadır. Çalışanların konuşmaya çekinmesi ve sessiz kalmayı tercih etmesi çalışanların işletmede maruz kaldıkları psikolojik iklimin göstergesi olmaktadır (Bass \& Avolio 1990). Liderler işletmenin imkanları dahilinde yapabildiği ve yapamadığı tüm fonksiyonlarından sorumlu kişiler olarak görülmektedir. Bu bağlamda lider kendi çerçevesinden düşündüğünde işletmenin tüm yetenek ve kabiliyetlerinden sorumlu olduğunu düşündügünde işletmenin atıl kaynaklarını kullanmayı bir görev olarak kendinde görebilmelidir. İşletmenin tüm kaynaklarını verimli ve etkin bir süreçte kullanmak için bu kaynakların farkında varmalıdır. İşgören sesliliği kaynak yaklaşımına göre işletmenin bilgi ve tecrübesinin kaynağı olan çalışanlarının yönetim sürecine katılmasının bir aracı olarak görülebilir. İç girişimcilik davranışı rekabet avantajı elde etmek için işletme içinde çalışanların işletmenin atıl kaynaklarını verimli ve etkin bir şekilde kullanmasının alternatif yolları olarak kabul edilebilir (Pinchot 1985). Bu açıdan bakıldığında işletmenin kaynaklarından biri olan işgören kaynağının işletme sürecinin kendilerine ait olan kısmına hakim olduğu yani bilgi ve deneyim sahibi olduğu düşünülürse çalışan kaynağının paha biçilmez düşünceleri verimlilik ve etkinliği artırmak için bir araç olarak kullanılabilir. Yani çalışanların işle ilgili konularda verimlilik ve etkinliği artıracak gözlem, kaygı ve önerilerini ifade etmeleri sayesinde işletmenin atıl kaynakları işletme sürecinin içine etkin bir şekilde sokulabilir. 
Levine ve Tyson (1990) yaptıkları çalışmada yüksek iş güvenliği ve güçlü kişilerarası ilişkilerin sonucunda işgörenlerde sadakat duygusu oluştuğunu ve kendilerini işletmeyle özdeşleştirdiğini ifade etmektedirler. Kendilerini işletmeyle özdeşleştiren çalışanların işletme sürecinde aktif olarak yer alarak öneri ve diğer yollarla verimlilik ve etkinliği artırmaya çalıştıkları ifade edilmektedir (Bae et al. 2010). Yukarıda anlatılanlar çerçevesinde aşağıdaki hipotez oluşturulmuştur:

$\mathrm{H}_{3}$ İşgören sesliliği davranışı iç girişimciliği olumlu ve anlamlı bir şekilde etkilemektedir.

\section{İşgören Sesliliğinin Aracı Rolü}

Aracı değiş̧kenli araştırma modellerinde bağımlı değişkenin bağımsız değişkenin dışında bağımsız değişkenin de etkilediği gizli bir değişken tarafından yordanabileceği önerilmektedir (Baron \& Kenny 1986). Bu bağlamda iç girişimcilik davranışlarının liderin güdüleyici dil kullanımıyla artacağı yukarıda belirtilen literatür taraması 1şığında önerilmektedir. Bunun yanında güdüleyici dil kullanımıyla oluşan işgören sesliliği olgusunun da iç girişimcilik davranışını olumlu olarak etkileyebileceği önerilmektedir. Yukarıda ilgili literatür taramasında anlatıldığı gibi iç girişimcilik davranışının liderin güdüleyici dil kullanımının oluşturabileceği yenilikçilik, yaratıcılık, risk alma davranışlarıyla artacağı ilgili alanyazı çalışmalarında önerilmektedir. Bunun yanında yukarıda literatür taramasında farklı çalışmalarda iç girişimcilik davranışının işgören sesliliğinin oluşturacağı sezgisel, yenilikçi ve yaratıcı davranışlar yoluyla da artacağı önerilmektedir. Güdüleyici dil ve işgören sesliliğinin ilişkisine yönelik yapılan çalışmalarda da güdüleyici dil ve iç girişimcilik olgusu arasında anlamlı ilişkinin olduğu önerilmektedir.

$\mathrm{Bu}$ bağlamda güdüleyici dil kullanımı ve iç girişimcilik davranışının arasındaki ilişkide işgören sesliliğinin aracı rol oynadığı önerilmektedir. Bu anlatılanlar 1şığında aşağıdaki hipotez oluşturulmuştur.

$\mathrm{H}_{4}$ İşgören Sesliliği olgusunun güdüleyici dil ve iç girişimcilik arasında aracı rolü vardır.

\section{Yöntem}

Araştırmada aracı değiş̧kenli model kullanılarak güdüleyici dil kullanımının iç girişimcilik davranışına olan etkisinde işgören sesliliğinin aracı rolü irdelenmiştir. Aracı değişkenli modeller bağımsız ve bağımlı değişken arasındaki ilişkide bağımlı değişken üzerinde etkisinin olduğu varsayılan gizli bağımsız değişken olduğu varsayılır (Baron \& Kenny 1986). Aracı değişkenin kullanıldığı araştırma modellerinde birkaç varsayımın sağlanması gerekmektedir. Bu varsayımlar (Baron \& Kenny 1986);

- Bağımsız değişkenin bağımlı değişkeni anlamlı bir şekilde etkilemesi gerekmektedir (c yolu).

- Bağımsız değişkenin aracı değişkeni anlamı bir şekilde etkilemesi gerekmektedir (a yolu).

- Aracı değişkenin bağımlı değişkeni anlamlı bir şekilde etkilemesi gerekmektedir (b yolu).

- Aracı değişken bağımlı değişken ve bağımsız değişken arasındaki ilişkiden çekildiğinde bağımsız değişkenin aracı değişken üzerindeki etkisinin anlamını yitirmesi durumunda tam aracılık etkisinden bahsedilir. Aracı değişken ilişkiden çekildiğinde bağımsız değişkenin aracı değişken üzerindeki etkisi devam ederken etki seviyesi düşerse kısmi aracılık rolünden bahsedilir (c' yolu).

$\mathrm{Bu}$ varsayımların model üzerindeki yansıması Figür 1'de görüldüğü gibidir: 


\section{Ölçme Araçları}

İşgören sesliliği ölçeği (İSÖ) orijinali van Dyne ve LePine (1998) tarafından geliştirilmiş 6 maddelik tek boyutlu bir ölçektir. Ölçeğin Türkçeye standardizasyonu Arslan ve Yener (2016) tarafindan yapılmıştır.

Araştırmamızda Güdüleyici Dil olgusunu ölçmek için Türkçe'ye uyarlaması Özen (2013) tarafindan yapılan 17 maddelik "Güdüleyici Dil Ölçeğì” kullanılmıştır.

İç girişimcilik davranışını ölçmek için Naktiyok (2004)

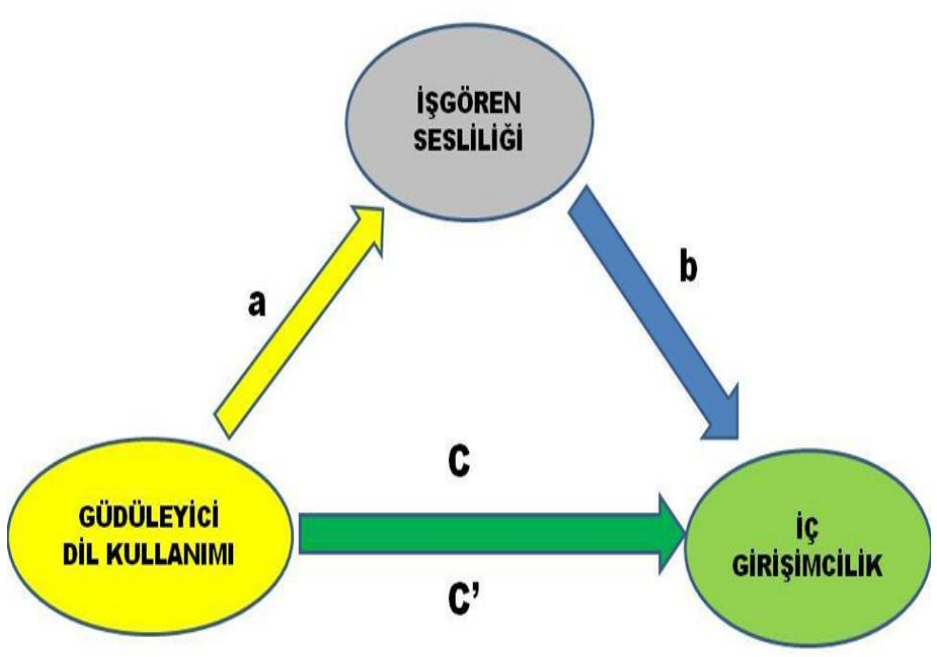

Fig. 1. Güdüleyici Dil Kullanımının İç Girişimcilik Davranışına Olan Etkisinde İşgören Sesliliğinin Aracı Rolü tarafından geliştirilmiş "İç Girişimcilik Ölçeğil” kullanılmıştır. İç girişimcilik ölçeği 18 maddeden oluşmaktadır.

Bireylerin kendi beyanlarına dayalı ölçme araçları 5'li likert (1 Kesinlikle Katılmıyorum - 5 Kesinlikle Katılıyorum) tipi bir tepki skalasına sahiptir. Ölçeklerin puanlanabilmesi için herhangi bir maddesinin ters kodlanmasına gerek yoktur.

Ölçeklerin uygunluğuna ait analiz sonuçları Tablo 1' de sunulmuştur. Buna göre örneklem uygunluğunun tüm ölçme araçları için yeterli olduğu değerlendirilmektedir. Analiz esnasında faktör yükleri \%40'ın altında olan veya birden fazla faktör altında toplanan maddeler de çıkartılarak, özdeğeri 1'in üzerinde olan faktörler analize tabi tutulmuş olup tabloda her bir ölçeğin kaç tane faktörü olduğu da ayrıca verilmiştir. Ölçeklerin genel güvenirlik katsayıları da tabloda yer almakta olup tüm ölçekler için sonuçların anlamlı ve uygun olduğu ileri sürülebilir.

Tablo 1. Güvenirlik Sonuçları

\begin{tabular}{|l|c|c|c|}
\hline Yapılan Test & Güdüleyici Dil Ölçeği & İşgören Sesliliği Ölçeği & Iç Girişimcilik Ölçeği \\
\hline KMO ve Barlett Uygunluk Testi & $0,83(\mathrm{p}<.001)$ & $0,74(\mathrm{p}<.001)$ & $0,89(\mathrm{p}<.001)$ \\
\hline Faktör Yüklerine Göre Faktör & 6 Faktör & 2 Faktör & 3 Faktör \\
Sayısı ve Toplam Varyansı & 24 Madde & 6 Madde & 18 Madde \\
Açıklama Oran1 & $\% 73,04$ & $\% 63,18$ & $\% 69,79$ \\
\hline Güvenirlik Sonuçları & $\alpha=0,89$ & $\alpha=0,73$ & $\alpha=0,91$ \\
\hline
\end{tabular}

\section{Araştırmanın Örneklemi}

Araştırmanın örneklemini Sinop'ta faaliyet gösteren bir tekstil üretim fabrikasının 205 çalışanı oluşturmaktadır. Anket için hazırlanan 250 adet formun 221 tanesi geri dönmüş olup 9 tanesinin geçersiz sayılması sonucu analizler 212 form üzerinden yapılmıştır. Araştırma örnekleminin 135 tanesi kadın 77 tanesi erkektir. 147 katılımci ortaokul, 57 tanesi Lise-MYO, 8 tanesi lisans mezunudur. 16 tanesi bölüm, unsure şefi, yönetici ve yönetici yardımcısı konumunda çalışırken 196 tanesi düz çalışan konumundadır. Araçtırmanın örnekleminin özelliklerini gösteren çapraz tablolar aşağıdadır. 
Tablo 2. Katılımcıların Eğitim-Cinsiyet Çapraz Tablosu

\begin{tabular}{|c|c|c|c|c|c|c|}
\hline \multicolumn{7}{|c|}{ Cinsiyet * Eğitim Durumunuz (Crosstabulation) } \\
\hline & & \multirow[b]{3}{*}{ Say1 } & \multicolumn{3}{|c|}{ Eğitim Durumu } & \multirow{3}{*}{$\begin{array}{c}\text { Total } \\
135\end{array}$} \\
\hline \multirow{5}{*}{ Cinsiyet } & \multirow{3}{*}{ Kadın } & & Ortaokul & Lise-MYO & Lisans ve üstü & \\
\hline & & & 115 & 18 & 2 & \\
\hline & & Toplam \%'si & $54,2 \%$ & $8,5 \%$ &, $9 \%$ & $63,7 \%$ \\
\hline & \multirow[t]{2}{*}{ Erkek } & Say1 & 32 & 39 & 6 & 77 \\
\hline & & Toplam \%'si & $15,1 \%$ & $18,4 \%$ & $2,8 \%$ & $36,3 \%$ \\
\hline \multicolumn{2}{|l|}{ Toplam } & Sayı & 147 & 57 & 8 & 212 \\
\hline
\end{tabular}

Tablo 3. Katılımcıların Konum-Yaş Çapraz Tablosu

\begin{tabular}{|c|c|c|c|c|c|}
\hline & & & \multicolumn{2}{|c|}{ İşteki Konum } & \multirow[b]{2}{*}{ Toplam } \\
\hline & & & Yönetici-Yönetici Yrd. & Çalışan & \\
\hline \multirow[t]{6}{*}{ Yaşınız } & \multirow[t]{2}{*}{$18-25$} & Say1 & 4 & 111 & 115 \\
\hline & & Toplamın \%'si & $1,9 \%$ & $52,4 \%$ & $54,2 \%$ \\
\hline & \multirow[t]{2}{*}{$26-33$} & Say1 & 3 & 59 & 62 \\
\hline & & Toplamın \%'si & $1,4 \%$ & $27,8 \%$ & $29,2 \%$ \\
\hline & \multirow[t]{2}{*}{$34-41$} & Say1 & 9 & 26 & 35 \\
\hline & & Toplamın \%'si & $4,2 \%$ & $12,3 \%$ & $16,5 \%$ \\
\hline \multicolumn{2}{|l|}{ Toplam } & Say1 & 16 & 196 & 212 \\
\hline
\end{tabular}

Araştırma örneklemini oluşturan 135 kadının 2 tanesi yüksekokul/ lisans mezunuyken 18 tanesi lise, kalan kısmı ortaokul mezunudur. 77 erkeğin 6 tanesi yüksekokul/ lisans mezunuyken 39 tanesi lise, kalan kısmı ortaokul mezunudur. Toplam 212 katılımcının 16 tanesi kendini yönetici/yönetici yardımcısı olarak beyan ederken 196 tanesi kendini çalışan olarak beyan etmiştir.

\section{Bulgular ve Yorum}

\section{Ön Analiz}

Araştırmada kullanılan değişkenlerin anket sonuçlarının analizine başlamadan önce yapılan normallik testi sonucu aşağıdadır. Parametrik ya da Nonparametrik hipotez testlerinin seçimini etkileyen normallik ve homojen dağılım testlerinin yapılması önerilmektedir (Büyüköztürk 2010, 39).

Tablo 4. Normallik Testi

Tek Örneklem Kolmogorov-Smirnov Testi

\begin{tabular}{|l|l|l|l|l|}
\hline & & MotDilÖ & İşGöSes & İçgirişort \\
\hline $\mathrm{N}$ & & 212 & 212 & 212 \\
\hline Normal Parameterler & & 2,3984 & 2,2947 & 2,5653 \\
& Ortalama &, 58584 &, 60068 &, 39046 \\
\hline En Uç Farklılıklar & Std. Sapma &, 078 &, 091 &, 068 \\
\cline { 3 - 5 } & Kesin Değerler &, 078 &, 091 &, 068 \\
\cline { 2 - 4 } & Pozitif & & & \\
\hline
\end{tabular}




\begin{tabular}{|c|c|c|c|}
\hline Negatif &,- 068 &,- 042 &,- 036 \\
\hline Kolmogorov-Smirnov Z & 1,140 & 1,323 & ,991 \\
\hline 2 Kuyruklu Anlamlılık Değeri &, 148 &, 060 & ,280 \\
\hline
\end{tabular}

Anlamlılık sütununa bakıldığında tüm değerlerin kritik değer olan 0,05 değerinden büyük olduğu için very dağılımının normal olduğu varsayılmıştır. Araştırma verilerinin dağılımıyla ilgili yapılan test sonucu dağılımın homojen olduğunu ortaya koyduğu için istatiksel analizlerde parametric testler kullanılmıştır. Homojen dağılım testinin sonuçlarına bakıldığında anlamlılık değerleri biri hariç kritik değer olan 0,05 değerinin üzerinde olduğu için veriler homojen dağılmış olarak varsayılmıştır. Kritik değerin altında çıkan değer ise 0,041 olup kritik değere çok yakın olduğu için homojen dağılım olduğu varsayılmıştır. Aracı değişken analizleri uygulayacağımız SPSS programında regresyon analizleri için normallik ve homojenlik gereklerinin yerine getirilmesi beklenmektedir. Benzer şekilde regresyon analizleri yapan WarPLS vb. programlarda bu şart aranmasa da birçok araştırmacı yaptıkları incelemelerde bu verileri aramaktadır.

\section{Bulgular}

Hipotezler sınanmadan önce değişkenler arasındaki ilişkinin varlığı araştırılmış ve Pearson korelasyon katsayılarına ait sonuçlar Tablo 5'de verilmiştir. Güdüleyici dil ve iç girişimcilik arasında olumlu ve anlamlı bir ilişkinin olduğu, $(0,39 ; \mathrm{p}<0,01)$, güdüleyici dil ve işgören sesliliği arasında olumlu ve anlamlı bir ilişkinin ortaya çıktığı, $(0,48 ; p<0,01)$ ve işgören sesliliği ve iç girişimcilik arasında olumlu ve anlamlı bir ilişkinin olduğu $(0,72 ; p<0,01)$ gözlenmiştir.

Tablo 5. Değişkenler Arası Korelasyon Test Sonuçları

\begin{tabular}{|l|r|r|r|r|r|}
\hline $\mathrm{n}=212$ & Mean & SD & 1 & 2 & 3 \\
Güdüleyici Dil Kullanımı & 2,39 & 0,58 & 1 & & \\
İşgören Sesliliği & 2,29 & 0,60 &, $48 * *$ & 1 & \\
İç Girişimcilik & 2,56 & 0,39 &, $39 * *$ &, $72 * *$ & 1 \\
\hline
\end{tabular}

Regresyon ve aracı model test sonuçlarına bakıldığında aracı değişken modellerin şartlarına gore bağımsız değişken olan güdüleyici dilin iç girişimciliği olumlu ve anlamlı bir şekilde etkilediği $\left(\mathrm{R}^{2}=0,45, \beta=-0,52\right.$ ve $\left.\mathrm{p}<0.01\right)$, bağımsız değişken olan güdüleyici dilin aracı değişken olan işgören sesliliğini olumlu ve anlamlı bir şekilde yordadığ $\left(R^{2}=0,23, \beta=-0,50\right.$ ve $p$ $<0.01$ ), aracı değişken olan işgören sesliliğinin iç girişimciliği olumlu ve anlamlı bir şekilde yordadığı $\beta=-0,33$ ve $p<0.01$ ) görülmüştür. Bağımsız değişken olan güdüleyici dil ve bağımlı değişken olan iç girişimcilik arasındaki ilişkiye işgören sesliliği aracı değişken olarak dahil edildiğinde bu etki düşmüş fakat anlamlılığını yitirmemiş̧tir $\left(\mathrm{R}^{2}=0,34, \beta=-0,36\right.$ ve $\left.\mathrm{p}<0.01\right)$. Araştırma sonuçlarını teyit etmek üzere yapılan sobel testinde de görüleceği üzere aracı değişken olan işgören sesliliğinin güdüleyici dil ve iç girişimcilik arasında kısmi aracılık etkisi gözlenmiştir $(\beta=0,36)$. Aracı değişken iş gören sesliliği bağımsız değişken güdüleyici dilin etkisini düşürmüş fakat ilişkinin anlamlılığı devam etmektedir. İlişkinin anlamlılığı da ortadan kalksaydı tam aracılık rolünden bahsedilebilirdi (Hayes, 2013). 
Tablo 7. Regresyon-Aracı ve Sobel Test Sonuçları

\begin{tabular}{|c|c|c|c|c|c|c|}
\hline \multicolumn{7}{|c|}{ Arac1 Model (Baron ve Kenny, 1986; HayesProcess 2.15) } \\
\hline Doğrudan Etkiler & Katsay 1 & $\begin{array}{l}\text { Standart } \\
\text { Sapma }\end{array}$ & $t$ & $p$ & $R^{2}$ & \\
\hline \multicolumn{7}{|l|}{ İşgören Sesliliği D.V. } \\
\hline Sabit & 1,09 & .1525 & 7,1809 & .000 & & \\
\hline Güdüleyici Dil I.D. & .50 & ,0618 & 8,1000 & .000 & $.23^{* *}$ & $\mathrm{a}$ \\
\hline \multicolumn{7}{|l|}{ İç Girişimcilik D.V. } \\
\hline Sabit & ,7681 & .1261 & 6,0891 & .000 & & \\
\hline İç Girişimcilik M.V. & ,3303 & .0512 & 6,4571 & .000 & & $\mathrm{~b}$ \\
\hline $\begin{array}{l}\text { Güdüleyici Dil Kullanımı } \\
\text { I.D. }\end{array}$ & .3589 & .0525 & 6,8427 & .000 & $.45^{* *}$ & $c^{\prime}$ \\
\hline \multirow{3}{*}{$\begin{array}{l}\text { Sobel Test } \\
\text { Dolaylı Etki }\end{array}$} & Eff. & & $z$ & & & \\
\hline & .16 & .040 & 5,025 & .000 & & \\
\hline & Eff. & SD & LLCI & & ULCI & \\
\hline & .16 & .032 & .1051 & & .2331 & $c^{\prime}$ \\
\hline \multirow[t]{2}{*}{ Toplam Etki } & Eff. & SD & $t$ & $p$ & $\mathrm{R} 2$ & \\
\hline & .52 & .0500 & 10,47 & .000 &, $34 * *$ & $\mathrm{c}$ \\
\hline \multicolumn{7}{|l|}{$* * * p<.001 ; \mathrm{n}=195$} \\
\hline $\begin{array}{l}\text { D.V.= Bağımlı Değişken; } \\
\text { Bootst SH=Bootstrap Stand }\end{array}$ & $\begin{array}{l}\mathrm{V} .=\mathrm{B} \\
\text { it Sapr }\end{array}$ & $\begin{array}{l}11 \mathrm{De} \\
=\mathrm{Gü}\end{array}$ & $\mathrm{M} . \mathrm{V} .=$ & & & \\
\hline
\end{tabular}

\section{Sonuç ve Tartışma}

Liderin kullandığı güdüleyici dilin konu olduğu çalışmalar alanyazında genellikle eğitim kurumları olmuştur (Arslan \& Yener 2016). Bu çalışmalarda güdüleyici dil kullanımıyla çalışanların etkilenerek yenilikçi ve yaratıcı bakış açılarıyla öğrenme problemlerine sonuç bulması sorgulanmıştır. Yenilik ve yaratıcılık bağlamından bakıldığında bu olguların iç girişimcilik davranışını da etkilediği (Lomberg 2009) gözönüne alındığında liderin güdüleyici dilinin kar amaçlı işletmelerde rekabet avantajını sağlamak için verimlilik ve etkinliği iç girişimcilik yoluyla artırma amaçlı kullanılabileceği düşünülmüştür. Araştırma sonuçlarına bakıldığında karşılıklı ilişkilere dayalı kullanılan güdüleyici dilin liderin ve örgütün misyon ve vizyonunun çalışanlarca kabul edilmesini sağlayabileceği görülmüştür. Örgütlerde güdüleyici dilin kullanılmasıyla oluşabilecek farklı olguların da olumlu sonuçlar doğurabileceği farklı çalışmalarda ortaya konmuştur (Arslan \& Yener 2016). Bu olgulardan en önemlilerinden bir tanesi son y1llarda pozitif psikoloji alanınında yaygın çalışma konularından olan işgören sesliliği olgusudur. Temelde kişilerarası ilişkilerde güven faktörüne dayalı bir olgu olan işgören sesliliği olgusunun çalışanlarda sezgisel davranışlar yoluyla yenilikçilik ve yaratıcılığı olumlu etkileyebileceği alanyazında yapılan çalışmalarda gözlemlenmiştir (Arslan \& Yener 2016). Bu gözlemlerle birlikte özellikle Motivasyonel dil kuramı (Sullivan 1988) ve Kaçma-konuşma- sadakat kuramı (Hirscman 1970) ve Sosyal Mübadele kuramlarının önerileri de gözönüne alındığında güdüleyici dilin iç girişimciliği işgören sesliliği üzerinden etkileyebileceği düşünülmüştür. Araştırma sonuçlarına bakıldığında işgören sesliliğinin motivasyonel dil kullanımının bir sonucu olduğunu göstermesi ve iç girişimcilik olgusunun yordayıcısı olduğunun gözlenmesi bağlantılı farklı olgularla yeni araştırmaların yapılabileceğini de düşündürmektedir. Bu konuda Yener'in (2015) 
çalışmalarında kullanmış olduğu 'Psikolojik Rahatlık' algısı örnek verilebilir. Araştırmacının yapmış olduğu farklı çalışmalarda işgören sesliliği gibi pozitif psikolojinin bileşenlerinden bir tanesi olarak psikolojik rahatlık algısı inovasyon güdümlü işletmelerin örgütsel ikliminin parçası olarak görülmektedir. Örnek vermek gerekirse inovasyona dayalı işletme sürecine sahip Google "Aristotle" projesiyle yenilikçi ve yaratıcı takımlar oluşturmak için psikolojik rahatlık algısını hedef davranış olarak seçmiştir. Araştırmalarda psikolojik rahaltık algısının işgören sesliliğinin belirleyici olduğu iddia edilmektedir (Yener, 2016). Güdüleyici dil davranışının işletmelerdeki etkilerini sorgulayan ve farklı olgularla ilişkisini ortaya koyan yeni araştırmalar yapılabilir. Özellikle işgören sesliliğinin belirleyeni olarak görülen psikolojik rahatlık olgusunun (Edmondson 2003) güdüleyici dil kullanımıyla birlikte çalışan performansı, örgütsel bağl1lık, sadakat olgularına etkisi sorgulanabilir. Diğer bir çalışma konusu olarak Sosyal mübadele kuramına (Blau 1964) gore örgütsel adalet olgusunun güdüleyici dil ve işgören sesliliği üzerinden yenilikçilik ve yaratıcılık olgularına olan etkisi sorgulanabilir. İşgörenlerin liderin davranışlarına yönelik algısının işletmede verimlilik ve etkinliğe ilişkin birçok konuyu doğrudan etkilediği gözönüne alınırsa bu olguların liderin davranışının değişmez bileşenleri olması gerektiği düşünülmektedir.

\section{KAYNAKÇA}

Antoncic B. \& Hisrich R. D. (2001). "Intrapreneurship: Construct Refinement and Cross-Cultural Validation". Journal of Business Venturing 16/5 (2001) 495-527.

Arslan A. \& Yener S. (2015). "İ̧̧ören Sesliliği Ölçeğinin Türkçe Formunun Geçerlik ve Güvenirlik Çalışması”. Yönetim ve Ekonomi Araştırmaları Dergisi 14/1 (2015).

Bae K., Chuma H., Kato T., Kim D. \& Ohashi I. (2010). "High Performance Work Practices and Employee Voice". IZA Discussion Paper (2010) 49-56.

Baron R. M. \& Kenny D. A. (1986). "The Moderator-Mediator Variable Distinction in Social Psychological Research: Conceptual, Strategic, and Statistical Considerations". Journal of Personality and Social Psychology 51/6 (1986) 11-73.

Bass B. M. (1985). Leadership and Performance beyond Expectations. New York 1985.

Bass B. M. \& Avolio B. J. (1990). Transformational Leadership Development: Manual for the Multifactor Leadership Questionnaire. California 1990.

Bass B. M. \& Riggio R. E. (2006). Transformational Leadership. Utah 2006.

Becker G. S. (1964). Human Capital Theory. Columbia 1964.

Blau P. M. (1964). Exchange and Power in social Life. New York 1964.

Büyüköztürk Ş. (2010). Sosyal Bilimler Íçin Veri Analizi El Kitabı. Ankara 2010.

Cappelli P. (2001). "Making the Most of On-Line Recruiting". Harvard Business Review 79/3 (2001) 139-46.

Detert J. R. \& Burris E. R. (2007). "Leadership Behavior and Employee Voice: Is the Door Really Open?". Academy of Management Journal 50/4 (2007) 869-884.

Edmondson A. (1999). "Psychological Safety and Learning Behavior in Work Teams". Administrative Science Quarterly 44/2 (1999) 350-383.

Fayolle A. (2004). Entrepreneuriat. Apprendre à Entreprendre. Paris 2004.

Helfat C. E. \& Lieberman M. B. (2002). "The Birth of Capabilities: Market Entry and the Importance of Pre-History". Industrial and Corporate Change 11/4 (2002) 725-760.

Hirschmann A. O. (1970). "Exit, Voice and Loyalty". Responses to Decline in Firms, Organizations, and States (1970). Cambridge.

Hisrich R. D. \& Peters M. P. (2002). Entrepreneurship. New York 2002.

Jong J. D. \& Wennekers S. (2008). "Intrapreneurship; Conceptualizing Entrepreneurial Employee Behavior". Scientific Analysis of Entrepreneurship and SMEs (SCALES), Zoetermeer: EIM (2008)1-47. 
Klepper S. \& Thompson P. (2006). "Intra-Industry Spinoffs". The Evolution of Ideas in Innovation and Entrepreneurship 36 (2006).

Kuratko F. K., Hornsby J. S. \& Sabatine F. J. (1999). The Breakthrough Experience: A Guide to Corporate Entrepreneurship. Muncie 1999.

Levine D. I. \& Tyson L. D. A.. "Participation, Productivity, and the Firm's Environment". Paying for Productivity (1990) 183-243. Washington.

Lomberg C. (2009) Kreativität im Kontext von Corporate Entrepreneurship. Dissertation Universität Duisburg-Essen 2009.

Mayfield J., Mayfield M. \& Kopf J. (1995). "Motivating Language: Exploring Theory with Scale Development". Journal of Business Communication 32/4 (1995) 329-344.

Mayfield M. \& Mayfield J. (2004). “The Effects of Leader Communication on Worker Innovation”. American Business Review 22/2 (2004) 46.

Mayfield J. \& Mayfield M. (2006). "The Benefits of Leader Communication on Part-Time Worker Outcomes: A Comparison between Part-Time and Full-Time Employees Using Motivating Language". Journal of Business Strategies 23/2 (2006) 131.

Mayfield J. \& Mayfield M. (2007). "The Effects of Leader Communication on a Worker's Intent to Stay: An Investigation Using Structural Equation Modeling”. Human Performance 20/2 (2007) 85-102.

Milliken F. J., Morrison E. W. \& Hewlin P. F. (2003). “An Exploratory Study of Employee Silence: Issues that Employees Don't Communicate Upward and Why”. Journal of Management Studies 40/6 (2003) 1453-1476.

Moriano J. A., Gorgievski M., Laguna M., Stephan U. \& Zarafshani K. (2011). “A Cross-Cultural Approach to Understanding Entrepreneurial Intention”. Journal of Career Development 39/2 (2011) 162-185.

Orhunbilge N. (2000). Örnekleme Yöntemleri ve Hipotez Testleri. İstanbul 2000.

Özen H. (2013). "Okul Müdürlerine Yönelik Güdüleyici Dil Ölçeği: Türk Kültürüne Uyarlama, Dil Geçerliği ve Faktör Yapısının İncelenmesi”. Eğitim Bilimleri Araştırmaları Dergisi 3/1 (2013) 87-103.

Pinchot G. (1985). Intrapreneuring: Why You Don't Have to Leave the Company to Become an Entrepreneur. New York 1985.

Pinchot G. (1986). “Intrapreneuring revisited”. European Management Journal 4/2 (1986) 89-94.

Rauch A., Wiklund J., Lumpkin G. T. \& Frese M. (2009). "Entrepreneurial Orientation and Business Performance: An Assessment of Past Research and Suggestions for the Future". Entrepreneurship Theory and Practice 33/3 (2009) 761-787.

Stephen P. R. (2003). Essentials of Organizational Behavior. Cincinnati 2003.

Sullivan W. M. (1986). Reconstructing Public Philosophy. California 1986.

Sullivan J. J. (1988). “Three Roles of Language in Motivation Theory”. Academy of Management Review 13/1 (1988) 104-115.

Van Dyne L. \& LePine J. A. (1998). "Helping and Voice Extra-Role Behaviors: Evidence of Construct and Predictive Validity”. Academy of Management Journal 41/1 (1998) 108-119.

Vandewalle D., van Dyne L. \& Kostova T. (1995). "Psychological Ownership: An Empirical Examination of its Consequences". Group \& Organization Management 20/2 (1995) 210-226.

Dyne L. V., Ang S. \& Botero I. C. (2003). "Conceptualizing Employee Silence and Employee Voice as Multidimensional Constructs”. Journal of Management Studies 40/6 (2003) 1359-1392.

Yener S. (2015). "Psikolojik Rahatlık Ölçeğinin Türkçe Formunun Geçerlik ve Güvenirlik Çalışması". Ordu Üniversitesi Sosyal Bilimler Araştırmalarl Dergisi (2015) 13.

Yener S. \& Arslan A. (2016). “Güdüleyici Dil, İşgören Sesliliği ve Örtük Bilgi Paylaşım Davranışı Etkileşiminde Psikolojik Rahatlığın Düzenleyici Rolü”. 15. Ulusal İşletme Kongresi, 99 Numaralı Bildiri, 26-28 May1s 2016, İstanbul Üniversitesi. İstanbul 2016.

Yener S. (2016). "İşgören Sesliliğinin Örgütlerde İşbirliğine Etkisinde Psikolojik Rahatlık Algısının Aracı Değişken Rolü”. 1. Avrasya Pozitif Psikoloji Kongresi, 28-30 Nisan 2016, Üsküdar Üniversitesi. İstanbul 2016. 